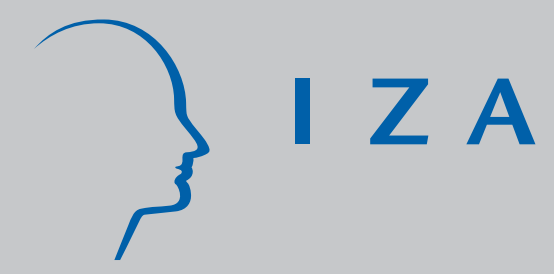

IZA DP No. 2522

An Experimental Investigation of Age Discrimination in the French Labour Market

Peter A. Riach

J udith Rich

December 2006 


\title{
An Experimental Investigation of Age Discrimination in the French Labour Market
}

\author{
Peter A. Riach \\ IZA Bonn (Research Fellow)
}

Judith Rich

University of Portsmouth and IZA Bonn

\section{Discussion Paper No. 2522 \\ December 2006}

\author{
IZA \\ P.O. Box 7240 \\ 53072 Bonn \\ Germany \\ Phone: +49-228-3894-0 \\ Fax: +49-228-3894-180 \\ E-mail: iza@iza.org
}

\begin{abstract}
Any opinions expressed here are those of the author(s) and not those of the institute. Research disseminated by IZA may include views on policy, but the institute itself takes no institutional policy positions.

The Institute for the Study of Labor (IZA) in Bonn is a local and virtual international research center and a place of communication between science, politics and business. IZA is an independent nonprofit company supported by Deutsche Post World Net. The center is associated with the University of Bonn and offers a stimulating research environment through its research networks, research support, and visitors and doctoral programs. IZA engages in (i) original and internationally competitive research in all fields of labor economics, (ii) development of policy concepts, and (iii) dissemination of research results and concepts to the interested public.
\end{abstract}

IZA Discussion Papers often represent preliminary work and are circulated to encourage discussion. Citation of such a paper should account for its provisional character. A revised version may be available directly from the author. 
IZA Discussion Paper No. 2522

December 2006

\section{ABSTRACT}

\section{An Experimental Investigation of Age Discrimination in the French Labour Market ${ }^{*}$}

In a field experiment of age discrimination, pairs of men aged twenty-seven and forty-seven, inquired, by email, about employment as waiters in twenty four French towns. The rate of net discrimination found against the older French waiter, corresponds to the highest rates ever recorded anywhere, by written tests, for racial discrimination. Discrimination was higher in Paris than in the rest of France.

JEL Classification: J71, C93

Keywords: age, discrimination, employment, field experiment, hiring

Corresponding author:

Judy Rich

Department of Economics

University of Portsmouth

Richmond Building

Portland Street

Portsmouth PO1 3DE

United Kingdom

E-mail: judy.rich@port.ac.uk

\footnotetext{
* We wish to thank Emma Riach for translating the résumés and Isabelle Fournier for assistance with French data.
} 
“He looks old to be a waiter” (White Teeth)

\section{Introduction}

The growing interest in field experiments, as a method of empirical investigation in economics, is demonstrated by the special issue of Advances in Economic Policy and Analysis, (2006, 6, issue 2) which is dedicated to field experiments. The first field experiment of discrimination in employment, which used pairs of matched, written job applications, was undertaken in the 1960s by Jowell and Prescott-Clarke (1970). They developed the technique to investigate racial discrimination in employment in England. The first time this experimental method was applied to investigate sexual discrimination in employment was in Melbourne during the 1980s (Riach and Rich, 1987).

Although it originated almost forty years ago, there has been virtually no application of this technique to measuring the extent of age discrimination in employment. This is surprising, given the widespread contemporary concern about the economic implications of the ageing population in Western countries, and the frequent recommendation that the only viable solution to the consequent "pensions' crisis" is an extended working life. For example the Organisation for Economic Co-operation and Development (OECD), referring to the old-age dependency ratio in France, states: “The ratio in France was around 27\% in 2000, nearly five percentage points higher than the average in OECD countries... In the coming decades, this ratio is set to increase in France at almost the same rate as the average in OECD countries, to reach $42 \%$ in 2025 and 58\% in 2050” (OECD 2005, p. 36). The French Government's response to this impending demographic difficulty has been to increase the retirement 
age, apply the work test more actively to unemployed persons over 50 and to consider the negative attitudes employers have to older workers.

The challenge in applying the experimental technique to age discrimination is the obvious variation in human capital across the generations. The logic of this experimental technique, as innovated by Jowell and Prescott Clarke, is to design the test so as to control strictly for human capital components such as education, qualifications, skills and experience, and so that the only distinguishing feature of the two job applicants is the characteristic, such as race or sex, which is being tested. The influence of race or sex on hiring decisions is consequently isolated. In the case of age there must inevitably be a variation in the job experience of the different age groups, and therefore a difficulty in determining whether any employment preference is attributable to a profit-maximizing response to differential human capital or to prejudice.

In our paper "Field Experiments of Discrimination in the Market-Place” (Riach and Rich 2002) we recommended that the technique should be adapted to the special case of older applicants; to accept that the job experience component of human capital does vary between different groups and have realistic candidates make applications, but to control for all other dimensions of human capital.

A frequent accusation against older applicants is that they are less mentally able/flexible and less physically active than their youthful competitors; “... numerous surveys and research conducted in the past 15 years point to negative employer perceptions vis-à-vis older workers with respect to their productivity, cost, work 
motivation, health, receptiveness towards training and ability to cope with technological and organisational change” (OECD 2004, p. 97; see also Purcell et al. 2003, pp. 3-4). However the objective scientific literature is to the contrary; "The finding from more than 100 research investigations is that there is no significant difference between the job performance of older and younger workers” (Warr 1994, p. 309).

We decided to confront such ageist attitudes by presenting an older applicant who was not more than forty-seven, who was engaged in strenuous physical activity and who demonstrated mental flexibility by an up-to-date interest in computers and information technology. In other words we controlled for the older candidate's mental and physical capacities, but not for his length of experience. In which case, if a preference were found for younger applicant with twenty years less experience, it would indicate a very significant level of prejudice against older applicants. On the other hand, if we were to find a preference for the older workers in such circumstances it could be interpreted as an economically rational response to human capital superiority, rather than prejudice against youth. The OECD recognises that; “...age discrimination is neither overt nor easily measured” (OECD 2004, p. 98). This is a challenge which we now address; what follows is a realistic attempt to measure age discrimination by using the experimental technique of forwarding matched, written job inquires.

\section{The experiment}

The intention was to have pairs of job applicants who were carefully-matched in all respects except in the experience which inevitably goes with age. An implication of this approach is that jobs with a career hierarchy were ruled out of the investigation. 
For instance, academics in their mid-twenties would be applying for different posts to those in their mid-forties: the former would be applying for post-doctoral fellowships or lectureships, whilst the latter would be applying for Chairs or Deanships. This is not to say that age discrimination may not be alive and well in academia, or in law, or in the civil service, but instead that it cannot be investigated by the technique of paired mail applications. We have chosen an occupation where it is realistic to expect that applications will come from candidates aged twenty years apart.

There are two techniques for applying this experimental method. The first is to respond to advertised vacancies, as innovated by Jowell and Prescott-Clarke in 1969, and surveyed by Riach and Rich (2002). The second is to conduct the investigation by forwarding unsolicited job inquiries to a group of employers in some occupation, as innovated by Fidell in 1970 and surveyed by Riach and Rich (2004b). The former procedure confronts the employer with simultaneous pairs of fictitious job applications at a time when he/she has initiated recruitment and they will be dealt with during the normal hiring process, but the application and observation rate, and therefore the duration of the study, is dependent on the state of the labour market. The latter procedure is more expedient; all that is required is an appropriate listing of employers in a particular occupation, and two mailings about a month apart, if the intention is to test matched pairs and if suspicion on the part of employers is to be allayed. This procedure is more appropriate in occupations where inquiries are customarily initiated from the supply side and in small business, so ensuring the inquiry is likely to be answered by the same person who normally takes hiring decisions. As inquiries must arrive at least a month apart there is some randomness in the extent to which they will coincide with a vacancy, therefore there can be less 
expectation of "equivalent treatment” (both candidates being offered interviews) than with the first procedure. Nevertheless, if in the first mailing fifty per cent of inquiries go from candidate $\mathrm{A}$ and fifty per cent from candidate $\mathrm{B}$, with reversal in the following month, this variation in timing will not bias the overall outcome of the experiment: i.e. there is control by age for the timing of application receipt. We decided to adopt the latter procedure and forward unsolicited job inquires by email in this study.

We sent unsolicited inquiries about possible job openings for male waiters to 345 hotels and restaurants throughout France. One applicant were twenty-seven and the other was forty-seven. In such an experimental investigation of age discrimination, for the reasons discussed above, it was not possible to perform any reversal of résumés. Both candidates had been educated for six years in a Lycee and had achieved the BEPC qualification. Both candidates had studied English and information technology subsequent to leaving school. We invented fictitious restaurant names for current employers. The efficacy of this tactic in particular, and the content of our résumés in general is confirmed by the receipt of positive responses from one restaurant with three Michelin stars, one with two Michelin stars and seven with one Michelin star. “Interests” were chosen to demonstrate the older applicant's physical fitness, and capacity to cope with modern technology. The "interests” were basketball, cycling and internet usage. The résumés of waiters were prepared in conjunction with advice from the accueil of a Michelin-listed restaurant in Provence. In any one emailing half the inquiries went from the older applicant and half from the younger, with reversal in the following month. The résumés used for the waiters are included in the Appendix. 
Positive responses were dealt with promptly and courteously with a reply explaining that alternative employment had already been secured. The ethical considerations involved in this deceptive procedure are dealt with in Riach and Rich (2004a).

\section{The results}

The outcome of this experiment is set out in Table 1 in a format which follows McIntosh and Smith (1974, p. 13) and which has since been adopted in field experiments across Europe; (see Riach and Rich 2002, pp. F486-F491). Column 4 shows the number of occasions when one or both applicants received a favourable response. This total is divided as follows: column 5 shows occasions when both received favourable responses (equal treatment); column 6 shows occasions when only the younger received a favourable response (discrimination against the older); and column 7 shows occasions when only the older received a favourable response (discrimination against the younger). Column 8 is net discrimination; that is 7 minus 6 , so that it is positive when the older applicant encountered more discrimination than the younger applicant. The statistical significance of any finding of net discrimination was determined by the application of the chi-square test. The data were categorised as accepted /rejected for two applicants in a 2*2 contingency table (Riach and Rich 2002, pp. F493 - F496). A comparison with French experimental results for race discrimination is provided in Table 2.

The highest net rate of discrimination ever previously recorded by the written experimental method was 66.7 percent against Antilleans in France in 1977 (Riach and Rich 2002, Table 4, p. F500). 
Our experiment conducted across 24 French towns from Strasbourg to Bordeaux and from Caen to Montpellier detected a level of net discrimination against the older applicant of 58.1 per cent. It is particularly significant that, when the Paris results are separated out, net discrimination falls from 58.1 per cent to 48 per cent; the younger candidate received eight favourable responses from Parisian restaurants, whereas the older candidate received none. This corresponds with our finding that discrimination against older waiters was much higher in London than in the rest of England (Riach and Rich 2006b).

\section{Interpretation}

Warr (1994) presents a classification of job activity in four categories, based on the relationship of performance to age. First are “age-impaired activities” in which there is a negative relationship between age and performance; “... basic capacities are exceeded to a greater extent for older people and experience cannot help. Tasks of that kind include continuous rapid information processing and some forms of strenuous physical activity” (Warr 1994, p. 314). Second are “age-counteracted activities”, in which there is no relationship between age and performance, because older people have strategies to compensate for any decline in information processing skills or in physical capacity. Third are "age-neutral activities", in which there is no relationship between age and performance, because the work is relatively undemanding and routine “... primary memory is apparently unaffected by age; older people are as able as their younger counterparts to hold in memory small amounts of information that are being used in uncomplicated cognitive activities” (Warr 1994, p. 317). Fourth are “age-enhanced activities” in which performance improves with age, because of the favourable impact of experience. 
Warr's framework provides an explanation for age-related employment preferences which arise from age-related human capital differences. Becker and Arrow/Phelps have provided the economic bases for employment preferences which arise from discriminatory attitudes in the market place. Becker’s (1971) theory proposes that customers, employers and/or current employees will sacrifice economic benefit, in order to indulge a "taste" for eschewing contact with some perceived pariah group. The Arrow/Phelps (1973/1972) hypothesis of "statistical discrimination" refers to the incomplete information, which employers have of the productivity and work characteristics of individual job applicants; this induces employers to resort to generalisations about the employment characteristics of groups, as a screening device to minimise the cost of information acquisition in the hiring process.

Waiters clearly come into Warr's category three, as the work is relatively undemanding and routine; also recall that our older French waiter plays competitive basketball, so his physical capacity to do the job can hardly be in doubt. The contrasting finding between Paris and the other 23 French cities indicates that statistical discrimination is also an unlikely explanation; it is not realistic to hypothesise that any constituent of incomplete information varies geographically in such a way as to activate this reaction. As long ago as 1933 George Orwell in Down and Out in Paris and London, (1940, pp. 68-9) recognized the strange symbiosis between waiter and diner. It certainly is an occupation with a critical interaction between employee and customer, and in an economic activity where repeat business is vital for commercial success. There is critical interaction, for instance, between nurse and patient, but few of us are repeat customers of hospitals. This might suggest particular insight in the casual aside quoted at the outset of this paper, which comes 
from the television adaptation of Zadie Smith's novel White Teeth, that is, customer prejudice à la Becker.

In their econometric study, which used data from the Workplace Employment Relations Survey, Daniel and Heywood found “...strong evidence for the role of deferred compensation and internal labour markets as a negative predictor of hiring older workers. This fits the hypothesis that efficient life-time incentive structures require hiring younger workers and employing them when old, but not hiring older workers.” (Daniel and Heywood, 2005 forthcoming, p. 15). However these factors cannot explain our results for waiters. Waiters do not operate in internal labour markets, nor do they benefit from deferred compensation.

The geographical variation between Paris and the rest of France is consistent with the results of our English study; we found a net rate of discrimination of 28.8 per cent for England, but the rate for London was 68.2 per cent. (Riach and Rich, 2006b). We postulated that the English results may be partly explained by differential unemployment rates. For the period of that experiment (July-September 2004) the Labour Force Survey records a rate of 7.2 percent for men in London, in contrast to a rate of 4.4 percent for the rest of England. When unemployment is high, and more applicants are searching, it facilitates the exercise of any discriminatory penchant which employers may have. Conversely when unemployment is low, and fewer applicants are searching, employers have less opportunity to discard applicants simply on the basis of some arbitrary characteristic such as race, sex or age. 
Such an explanation is not available for France however, as in 2005 the unemployment rate for Paris, for men aged 25-49, was 8.9 per cent; only marginally higher than the national figure of 8 per cent. 
Table 1: Results for the French Age Discrimination Tests

\begin{tabular}{|c|c|c|c|c|c|c|c|}
\hline $\begin{array}{c}1 \\
\text { Occupation }\end{array}$ & $\begin{array}{l}\quad 2 \\
\quad \text { Location of } \\
\text { test }\end{array}$ & \begin{tabular}{l}
\multicolumn{1}{c}{3} \\
Neither \\
invited
\end{tabular} & $\begin{array}{l}\quad 4 \\
\text { Usable } \\
\text { tests }\end{array}$ & $\begin{array}{c}5 \\
\text { Equal } \\
\text { treatment }\end{array}$ & \begin{tabular}{l}
\multicolumn{1}{c}{6} \\
Discrimination \\
against older
\end{tabular} & \begin{tabular}{l}
\multicolumn{1}{c}{7} \\
Discrimination \\
against younger
\end{tabular} & $\begin{array}{c}8 \\
\text { Net } \\
\text { Discrimination }\end{array}$ \\
\hline \multicolumn{8}{|l|}{ Waiter } \\
\hline Total (number) & France & & 31 & 1 & 24 & 6 & 18 \\
\hline Percent & & & 100 & 3.2 & 77.4 & 19.4 & $58.1^{* * *}$ \\
\hline Total Paris (number) & Paris & & 8 & 0 & 8 & 0 & $8 * * *$ \\
\hline Percent & & & 100 & 0 & 100 & 0 & 100 \\
\hline Total Rest of France (number) & Rest of & & 23 & 1 & 16 & 6 & $10 * *$ \\
\hline Percent & France & & 100 & 4.0 & 69.6 & 26.1 & 43.5 \\
\hline
\end{tabular}

Note 1: Chi-squared tests were conducted on the response rates and the results are indicated in column 8 - * significant at the 0.05 level; ** significant at the 0.01 level; *** significant at the 0.001 level. 
Table 2: Results for the French Race Discrimination Tests

\begin{tabular}{|c|c|c|c|c|c|c|c|}
\hline 1 & 2 & 3 & 4 & 5 & 6 & 7 & 8 \\
\hline Occupation & $\begin{array}{l}\text { Location of } \\
\text { test }\end{array}$ & $\begin{array}{l}\text { Neither } \\
\text { invited }\end{array}$ & $\begin{array}{l}\text { Usable } \\
\text { tests }\end{array}$ & $\begin{array}{l}\text { Equal } \\
\text { treatment }\end{array}$ & $\begin{array}{l}\text { Discrimination } \\
\text { against minority }\end{array}$ & $\begin{array}{l}\text { Discrimination } \\
\text { against white }\end{array}$ & $\begin{array}{c}\text { Net } \\
\text { Discrimination }\end{array}$ \\
\hline Non-manual jobs & France & 415 & $\begin{array}{l}267 \\
100\end{array}$ & $\begin{array}{c}55 \\
20.6\end{array}$ & $\begin{array}{l}195 \\
73.0\end{array}$ & $\begin{array}{l}17 \\
6.4\end{array}$ & $\begin{array}{l}178 \\
66.7 * * *\end{array}$ \\
\hline
\end{tabular}

Note : Chi-squared tests were conducted on the response rates and the results are indicated for net discrimination:

* significant at the 0.05 level; ** significant at the 0.01 level; *** significant at the 0.001 level 


\section{Appendix \\ Résumés used in the experiment \\ Résumé A}

Monsieur/Madame,

Je cherche actuellement une offre d'emploi comme serveur. Je travaille à Londres mais mon amie vient d'obtenir un travail à Aix-en-Provence, ainsi je veux également travailler à Aix-en-Provence. Je vous prie de trouver ci-joint mon curriculum vitae.

Veuillez agréer, Monsieur/Madame, mes salutations distinguées.

$\operatorname{XXXX}$

\section{Curriculum Vitae}

Né

Le 27 juillet 1978 à Tours

\section{Formation}

1988-1994 : Lycée Joue-les Tours

BEPC

1994 - L'anglais et l'informatique.

J'ai le permis de conduire.

\section{Emploi}

Pour mon premier travail j’ai été serveur dans un café à Tours. En 1997 j’ai obtenu un emploi dans un hôtel à Amboise comme serveur et depuis j'ai travaillé en hôtels et restaurants à Paris, et Londres. A présent je travaille chez Le Petit Canard à Londres.

\section{Intérêts}

Ordinateur

Cinéma

Volley-ball 


\section{Résumé B}

Monsieur/Madame,

Je vous envoie mon curriculum vitae puisque je souhaite obtenir un travail à Antibe. Je travaille actuellement à Londres, mais mon épouse souhaite retourner à Antibe pour s'occuper de son père. Je suis à votre disposition pour un entretien.

Veuillez agréer, Monsieur/Madame, mes salutations distinguées.

XXXX

\section{CURRICULUM VITAE}

Age- 47 ans

Marié avec deux enfants

\section{Formation}

Lycée Victor Hugo (Nantes) 1969-1974

BEPC

\section{Post-scolaire}

Anglais

Informatique (Word, Excel)

Vins du Monde

J'ai le permis de conduire

\section{Expérience professionnelle}

Je suis serveur en hôtels et restaurant depuis 1976, à Nante, Londres, et Paris. Depuis 2000 je travaille chez Pierre André à Londres

\section{Loisirs}

Basket-ball

Internet

Cyclisme 


\section{References}

Adams, Scott J. (2004). 'Age Discrimination Legislation and the Employment of Older Workers’, Labour Economics, Vol. 11, No., pp. 219-241.

Advances in Economic Analysis and Policy, 2006, Vol. 6, Issue 2.

Arrow, Kenneth (1973). 'The Theory of Discrimination, in Ashenfelter, Orley and Rees, Albert (eds.), Discrimination in Labor Markets, Princeton University Press, Princeton, pp.

Becker, Gary (1971). The Economics of Discrimination, $2^{\text {nd }}$ edition. University of Chicago Press, Chicago.

Daniel, Kirsten and Heywood, John S. (forthcoming). 'The Determinants of Hiring Older Workers’, Labour Economics (In Press).

Fidell, L. S. (1970). ‘Empirical Verification of Sex Discrimination in Hiring Practices in Psychology’, American Psychologist', Vol. 25, December, pp. 1094-98.

Jowell, Roger, and Prescott-Clarke, Patricia (1970). 'Racial discrimination and whitecollar workers in Britain', Race, Vol. 11, No. 4, pp. 397-417. 
McIntosh, Neil and Smith, David (1974). 'The Extent of Racial Discrimination', Political and Economic Planning Broadsheet no.547, Political and Economic Planning, London.

OECD (2005). Ageing and Employment Policy, France, Paris, OECD.

OECD (2004). Ageing and Employment Policy, United Kingdom, Paris, OECD.

Orwell, George (1940). Down and Out in Paris and London, Penguin, Harmondsworth, UK.

Penna Sanders and Sidney. (2002). 'Generation Flex to the Rescue?' http://www.management-issues.com.

Phelps, Edmund (1972). 'The Statistical Theory of Racism and Sexism', American Economic Review, Vol. 62, No. , pp. 659-661.

Purcell, Kate, Wilton, Nick, and Elias, Peter (2003). Older and wiser? age and experience in the graduate labour market. Researching Graduate Careers Seven Years On, Research paper no. 2. Warwick University, Warwick Institute for Employment Research.

Riach, Peter A. and Rich, Judith (2006). 'An Experimental Investigation of Age Discrimination in the English and Spanish Labour Markets', (unpublished). 
Riach, Peter A. and Rich, Judith (2004a). 'Deceptive Field Experiments of Discrimination: Are They Ethical?', KYKLOS, Vol. 57, Issue 3, pp. 457-470.

Riach, Peter A. and Rich, Judith (2004b). 'Fishing for Discrimination', Review of Social Economy, Vol. 61, No. 4, pp. 465-486.

Riach, Peter A. and Rich, Judith (2002). 'Field Experiments of Discrimination in the Market Place’, Economic Journal, Vol. 112, No. 483, pp. F480-F518.

Riach, Peter A. and Rich, Judith (1987). 'Testing for Sexual Discrimination in the Labour Market’, Australian Economic Papers, Vol. 26, No. , pp. 165 - 178.

Smith, Zadie (2000). White Teeth, Hamish Hamilton, London.

Warr, P. (1994). ‘Age and Job Performance’, In: Snel, Jan Cremer, Roel (eds.), Work and Aging: A European Perspective, Taylor and Francis, London, pp. 309-322. 